\title{
A METALLOGENIC EVOLUTION MODEL FOR THE LEAD-ZINC DEPOSITS OF THE MESO AND NEOPROTEROZOIC SEDIMENTARY BASINS OF THE SÃO FRANCISCO CRATON, BAHIA AND MINAS GERAIS, BRAZIL
}

\section{AROLDO MISI ${ }^{1}$, SUNDARAM S. IYER ${ }^{2}$, CARLOS E. SILVA COELHO ${ }^{1}$, COLOMBO C.G. TASSINARI ${ }^{3}$, WASHINGTON J. S. FRANCA-ROCHA ${ }^{1,4}$, ADRIANA S. ROCHA GOMES ${ }^{1,4}$, IONÁ ABREU CUNHA ${ }^{1,5}$ TEOPHILOUS TOULKERIDIS $^{6}$ AND ANDREIA LIMA SANCHES ${ }^{1}$}

\begin{abstract}
Integrated studies carried out on the Proterozoic sediment-hosted Pb-Zn sulfide deposits of the São Francisco Craton, Brazil, allowed the estimation of (1) ages of the host sequences, (2) timing of mineralization, (3) possible sources of metal and sulfur, (4) temperature and salinity range of mineralizing solutions, (5) sources of fluids and (6) possible mechanisms of fluid flow. Contrary to the deposits from other Proterozoic basins, the Brazilian deposits do not contain world class metal reserves. This can probably be attributed to the lack of sufficient investments in exploration and mining development research activities. However, the sulfide deposits of the São Francisco Craton do share several important geological, structural, isotopic and fluid characteristics with some of the giant deposit types. Using these data we develop a more realistic metallogenic model for the Proterozoic sediment-hosted $\mathrm{Pb}-\mathrm{Zn}$ sulfide deposits.
\end{abstract}

Keywords: metallogeny, lead-zinc, Proterozoic, Brazil

GEOTECTONIC SETTING The lead zinc silver-rich deposits and their host Proterozoic sedimentary basins in the São Francisco Craton are distributed over more than $300.000 \mathrm{~km}^{2}$ (Fig. 1). The majority of known deposits are hosted by Neoproterozoic dolomitic units of the Bambui Group and equivalents, with the exception of one small deposit (Caboclo) which is hosted by dolomitic lenses in the dominantly siliciclastic Caboclo Formation $(1.2 \mathrm{Ga})$ of the Chapada Diamantina Group (Espinhaço Supergroup). Only two of the deposits studied are being mined: Vazante, $8 \mathrm{Mt}(23 \% \mathrm{Zn})$ and Morro Agudo, $12 \mathrm{Mt}(6,4 \% \mathrm{Zn}, 2,2 \% \mathrm{~Pb})$, respectively producing $650.000 \mathrm{t} / \mathrm{year}$ (ROM) with $13,5 \% \mathrm{Zn}$ and $580.000 \mathrm{t} / \mathrm{year}$ (ROM) with 5\% $\mathrm{Zn}$ and $2 \%$ $\mathrm{Pb}$. They are hosted by dolostones of the Neoproterozoic Vazante Group, a folded counterpart of the Bambuí Group in the western border of the cratonic area.

The Mesoproterozoic basins of the Espinhaço Supergroup originated from a rifting structure, the Espinhaço Aulacogen, aligned NNW-SSE. The important geotectonic event is well defined by the typically anorogenic magmatism that occurs at the base of the Espinhaço Supergroup with age values of 1.76 to $1.8 \mathrm{Ga}$. The present configuration of the São Francisco Craton has been molded during the Brasiliano/Pan-African tectonic cycle (1.0 to $0.5 \mathrm{Ga})$. The fragmentation of the Rodinia supercontinent during this tectonic cycle and the subsequent inversion generated the Neoproterozoic extensional basins of São Francisco, Una and Una-Utinga, and the fold belts around the cratonic areas. It appears that the old extensional structures were active, even during this important compressional phase.

COMMON ATRIBUTES The major characteristics of all the deposits studied are: (1) Host rocks are shallow water marine carbonates, mainly of dolomitic type, associated with organic-rich facies: stromatolitic structures, black micritic and oolithic carbonates, and black schists and marls, with disseminated pyrite. (2) For the Neoproterozoic deposits the presence of nodules of length-slow microquartz, gypsum, sulfides pseudomorphs of sulfates, teepee structures and dissolution breccias indicate their intimate association with evaporitic facies. The evaporite and dolomitic facies correspond to an end member of a regressive megacycle. These mineralized facies are superposed by organic-rich pelites, representing a rising sea level (Fig. 2). (3) The majority of the deposits studied show a very clear structural control with (a) normal faults aligned N30-40E for Caboclo (b) fractures and faults oriented N40 to N50W for Una-Utinga basins (c) normal faults (N15-50E) for the Vazante and Morro Agudo (d) At Irecê, intense folding masks any pronounced fault association. Figure 3 shows that some of these structures, apparently associated with the mineralization, crosscut the sedimentary basin and its basement, implying that they were active at least until the end of the basin filling. (4) With the exception of the Vazante mine, where primary mineralization is essentially silicatic (willemite), in all other deposits sulfides (pyrite, galena and sphalerite) represent the main mineral association, with (i) dominant sphalerite in Morro Agudo and Irecê (ii) dominant galena in Caboclo, Nova Redenção, Montalvânia, and Januária/Itacarambi. Silver is present in all deposits. (5) The most common gangue minerals are calcite, dolomite, quartz (mega and microquartz) and barite (absent in Caboclo). In Caboclo, there is also an important hydrothermal alteration zone surrounding the sulfide mineralization, with microcline, biotite, quartz and tourmaline. (6) In all deposits, mineralization is stratiform and sub-stratiform, along with irregular patches and veins of massive sulfides. In Morro Agudo, four main types of ore bodies have been described by Romagna \& Costa (1988): N (stratiform), M (veins ?), JKL (massive, replacing oolitic dolostone) and GHI (massive, replacing brecciated dolostone).

Fluid inclusions studies Homogenization temperatures $\left(T_{H}\right)$ and salinities obtained from primary fluid inclusions in sphalerite crystals from Morro Agudo, Vazante, Nova Redenção and Irecê indicate many similarities. In Morro Agudo, $T_{H}$ and salinity varied according to the type of ore body and its location relative to the fault zone. There is a clear correlation between $\mathrm{T}_{H}$ and salinity distribution, and highest values being found close to the fault zone. For all the ore bodies, $\mathrm{T}_{\mathrm{H}}$ ranges from 80 to $300^{\circ} \mathrm{C}$ (modal value of $160^{\circ} \mathrm{C} ; \mathrm{n}=347$ ) and salinity between $14 \%$ and $22 \% \mathrm{NaCl}$ equiv. In Vazante, Dardenne and Freitas-Silva 1999 obtained from willemite crystals $\mathrm{T}_{\mathrm{H}}$ values ranging from $159^{\circ} \mathrm{C}$ to $170^{\circ} \mathrm{C}$ and salinities from 3 to $15 \% \mathrm{wt} \mathrm{Eq}$. Na $\mathrm{Cl}$. In Nova Redenção, $\mathrm{T}_{\mathrm{H}}$ values range from $80^{\circ} \mathrm{C}$ to $210^{\circ} \mathrm{C}$, mode of $185^{\circ} \mathrm{C}(\mathrm{n}=165)$ and salinity ranges from $10 \%$ to $25 \%$ wt. Eq. $\mathrm{NaCl}$. A limited number of analyses of sphalerites from Irecê mineralization indicated $\mathrm{T}_{\mathrm{H}}$ ranging from 140 to $200^{\circ} \mathrm{C}$ and salinity from $3 \%$ to $10 \%$ wt Eq. $\mathrm{NaCl}$ (Kyle \& Misi, 1997). A comparison of these data with those obtained for MVT, SEDEX and IRISH deposits (Fig. 4) suggests that Brazilian deposits are of the carbonate hosted and fault controlled type.

Isotopic data Lead isotope data obtained by the present authors (Iyer et al., 1992; Misi, 1999) and others (Amaral, 1968; Cassedanne \& Lassere, 1969) indicate the derivation of metals from upper crustal sources (Fig. 5). Despite an overall heterogenous distribution for different deposits, a near homogeneous distribution has been observed for some individual deposits. The deposits of Caboclo (Mesoproterozoic), Irecê and Nova Redenção, as well as the lead-zinc mineralizations of the São Francisco Basin (Neoproterozoic), show moderate to high radiogenic $\mathrm{Pb}$ isotope values, while the $\mathrm{Pb}$ isotope

1 - Grupo de Pesquisa em Metalogênese, Centro de Pesquisa em Geofísica e Geologia and Curso de Pós-Graduação em Geologia, Instituto de Geociências, Universidade Federal da Bahia. Rua Caetano Moura, 123 CEP 40210-340, Salvador, Bahia, Brazil. E-mail:misiufba.br

2 - Department of Physics and Astronomy, University of Calgary, Calgary, Alberta, Canada.

3 - Centro de Pesquisas Geocronológicas, Instituto de Geociências da Universidade de São Paulo, Brazil.

4 - Universidade Estadual de Feira de Santana, Feira de Santana, Bahia, Brazil.

5 - CEFET, Salvador, Bahia, Brazil.

6 - Universidad de San Francisco de Quito, Colegio de Ciencias, Quito, Ecuador 


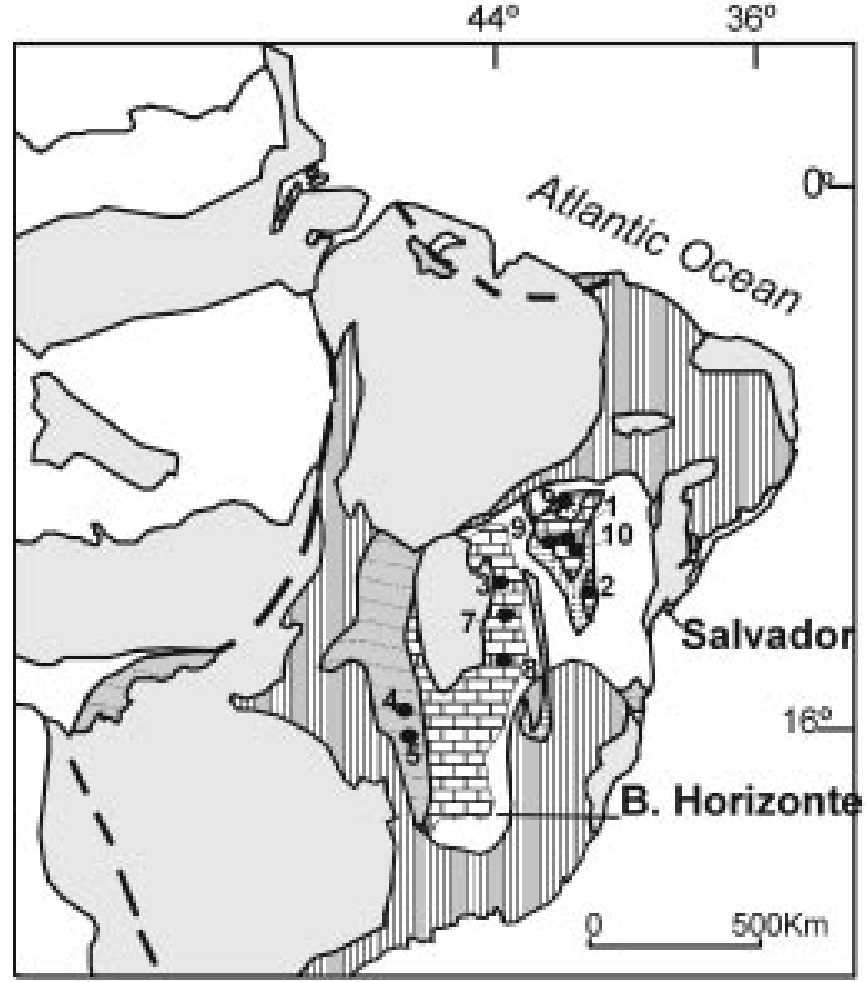

LEGEND

Phanerazoic

Bambui Group, Vazante Formation and Una Group.

进 Non metamorphic

Folded and low-grade metamorphic

\section{Fold belts ( $600 \mathrm{Ma})$}

IIII Metamorphic equivalents of the

Bambui Group and older deformed units

Figure 1 - Geotectonic setting and location of the main zinc-lead deposits of the Proterozoic sedimentary cover of the São Francisco Craton. 1 - Vazante 2 - Morro Agudo 3 - Januária/Itacarambí 4 - Montalvânia 5 - Serra do Ramalho $\mathbf{6}$ - Nova Redenção 7 - Irecê 8 - Morro do Gomes 9 - Melancias 10 - Caboclo (Mesoproterozoic).

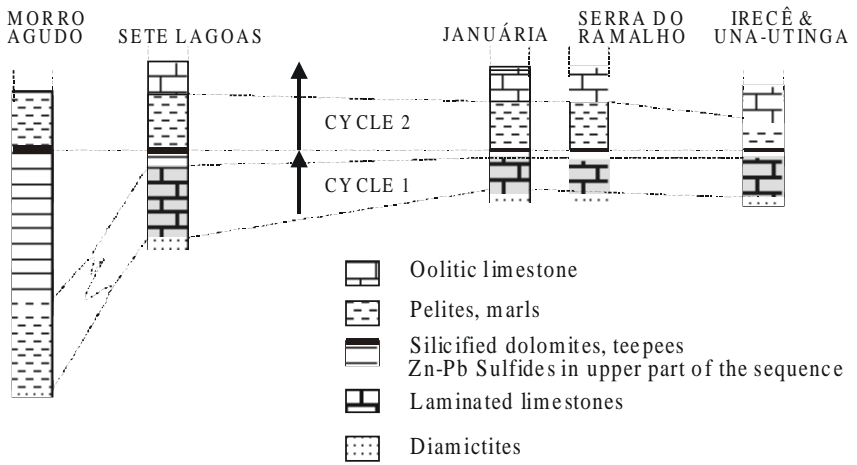

Figure 2 - Lithostratigraphic and chemostratigraphic correlations between the Neoproterozic sequences of the São Francisco Craton and the location of the $\mathrm{Zn}-\mathrm{Pb}$ deposits at the end of a regressive megacycle.

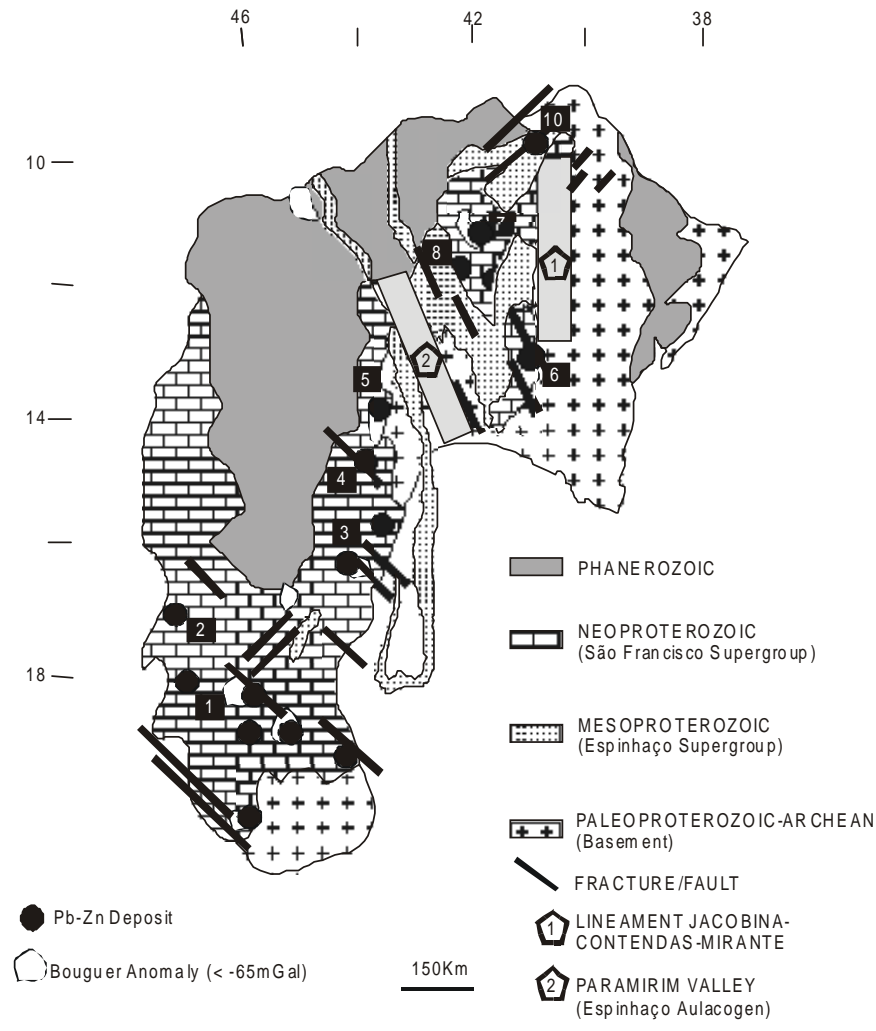

Figure 3 -Distribution of $\mathrm{Zn}-\mathrm{Pb}$ deposits in the São Francisco Craton and its association with fractures/faults and with oval shaped negative Bouguer anomalies. See Fig. 1 for the names of the main deposits.

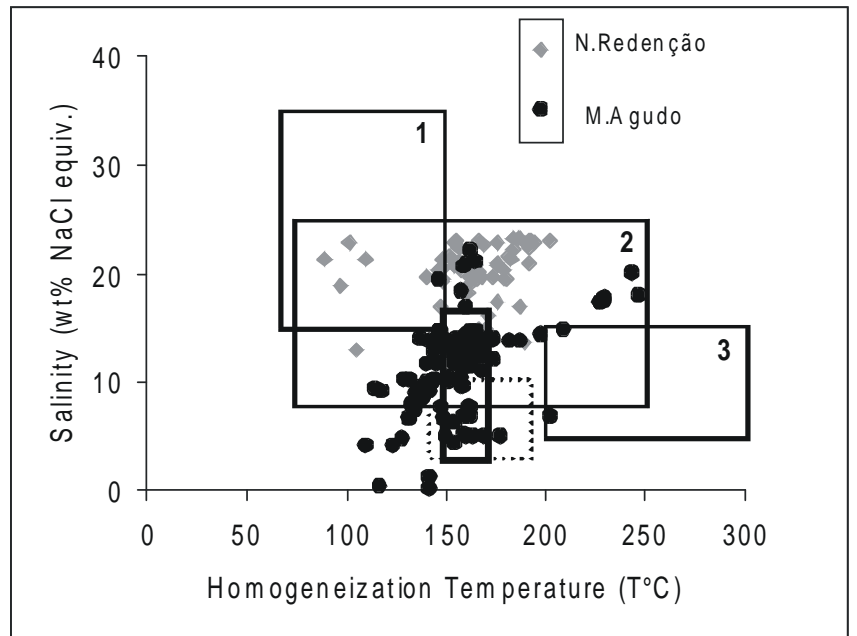

Figure 4 - Homogeneization temperatures $\left(T_{H}\right)$ and salinities from primary and pseudosecondary fluid inclusions in sphalerite from some Neoproterozoic $\mathrm{Zn}$-Pb deposits of the São Francisco Craton and comparison with classical sedimentogenic types. 1 - Mississipi Valley Type (MVT) 2 - Irish 3-SEDEX. Area within dotted lines: data of primary fluid inclusions from Irecê sphalerite. Area within dark lines: fluid inclusions in willemite from Vazante (Dardenne and Freitas Silva, 1999). 


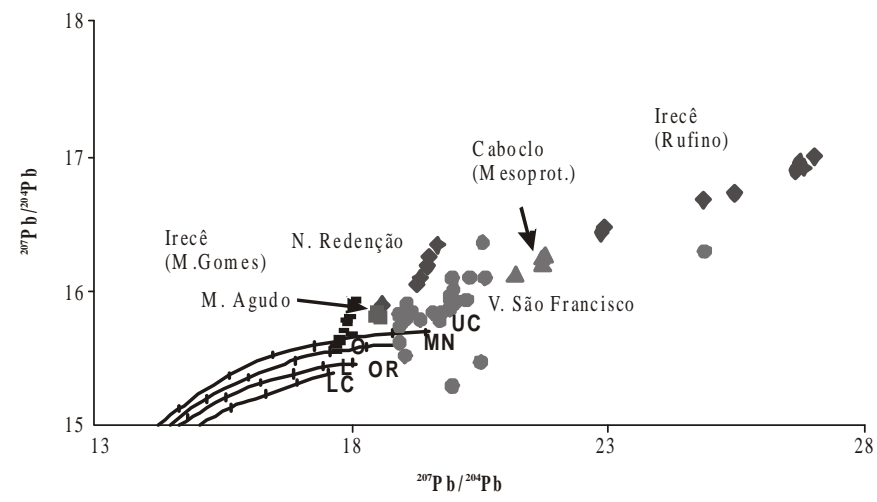

Figure 5 - Lead isotope composition of sulfides from the deposits studied. Evolution curve according to the plumbotectonic model of Zartman and Doe (1981). UC - Upper Crust MN - Mantle OR - Orogen LC - Lower Crust.

data for the deposits of Vazante and Morro Agudo are less radiogenic. The mean values obtained for ${ }^{206} \mathrm{~Pb} /{ }^{204} \mathrm{~Pb}$ ratios in these deposits are shown in table 1 .

Sulfur isotopic values were determined by the present authors for stratiform + nodular sulfates (barite and gypsum) and sulfides (mainly sphalerite, galena and pyrite) from the deposits of Irecê, Nova Redenção, Vazante and Morro Agudo and on galena crystals from the Caboclo deposit (Mesoproterozoic). The overlapping of $\delta^{34} S$ values for sulfates of the Neoproterozoic deposits with the data of coeval seawater sulfate (Claypool et al., 1980) indicate the derivation of the sulfur from seawater (Tab. 2).

The majority of the inclusion data and isotopic studies are from the MSc dissertations of W. Franca-Rocha, A. S. R. Gomes, A. L. Sanches, I. A. Cunha and other members of our research group. The database used here is available in Misi (1999) and is expected to be available soon in the following site: "http://www.cpgg.ufba.br/ metalogenese/".

DISCUSSION AND CONCLUSION For the Neoproterozoic deposits the sulfur isotopic data and the association of part of the mineralization with evaporitic features suggest the derivation of sulfur from a dominant seawater source. There is no clear evidence for a seawater sulfur source for the Mesoproterozoic deposit of Caboclo. Lack of correlation between the $\delta^{34} \mathrm{~S}$ and ${ }^{206} \mathrm{~Pb} /{ }^{204} \mathrm{~Pb}$ for samples from the Neoproterozoic deposits indicates the derivation of sulfur and metals from different sources. Temperatures above $120^{\circ} \mathrm{C}$, obtained from fluid inclusion study of sphalerite crystals in the deposits investigated, indicate thermochemical reduction of sulfates to be the dominant mechanism in the formation of the sulfides. However, in the Morro Agudo deposit, the sulfides may have formed by a more complex process: We observed a zoning pattern in sulfur isotopic data, with respect to the fault zone, whereby the heaviest $\delta^{34} S$ values (mean of $+34 \%$ CDT in the M ore body) are closer to the fault zone. The values drop to $-3.7 \%$. CDT in the $\mathrm{N}$ ore body, $120 \mathrm{~m}$ away from the fault in the same stratigraphic zone. Two different sulfur sources, one of them probably related to the addition of isotopically heavy sulfur from the hydrothermal fluid circulating in the fault zone, may be invoked to explain the zoning.

The Vazante deposit is mainly formed by willemite (zinc silicate) with minor amounts of sphalerite and galena. The near absence of sulfide minerals is attributed to a high oxygen fugacity during the mineralization event (Monteiro, 1998), a suggestion supported by the presence of abundant hematite and silica associated with the mineralization. In Vazante, sphalerite and galena yield relatively heavy $\delta^{34} \mathrm{~S}$ values, although much lower than the data from the Morro Agudo deposit.

The textures and features displayed by the deposits indicate a dominant process of replacement of the carbonate host rocks during the mineralization. Some features of the mineralization at Morro Agudo, Vazante, Nova Redenção and Irecê indicate a syngenetic or syndiagenetic mineralization, e.g. the presence of millimetric beds of ultra fine sphalerite in the $\mathrm{N}$ orebody at Morro Agudo, and the plastic deformation of the host carbonate by syn-sedimentary faults and by the growing of sulfide nodules in the other deposits.
Table 1 - Pb isotopic data of $\mathrm{Pb}-\mathrm{Zn}$ deposits of São Francisco Craton

\begin{tabular}{|c|c|}
\hline DEPOSIT & ${ }^{{ }^{206}} \mathbf{P b} /{ }^{\mathbf{2 0 4}} \mathbf{P b}$ \\
\hline Morro Agudo & $17,8 \pm 0,08$ \\
Vazante & $17,7 \pm 0,09$ \\
Vale do São Francisco & $21,2 \pm 4,18$ \\
Nova Redenção & $19,4 \pm 0,32$ \\
Irecê & $25,4 \pm 1,50$ \\
Caboclo (Mesoproterozoic) & $21,6 \pm 0,26$ \\
\hline
\end{tabular}

Table 2 - Sulfur Isotope data of sulfates and sulfides from $\mathrm{Pb}-\mathrm{Zn}$ deposits of the São Francisco Craton

\begin{tabular}{|c|c|c|c|}
\hline Irecê & $\begin{array}{c}\text { SULFATES } \\
(\% \circ \text { CDT) } \\
+29(\mathrm{n}=13)\end{array}$ & $\begin{array}{c}\text { SULFIDES } \\
(\% \circ \text { CDT) } \\
+23(\mathrm{n}=18)\end{array}$ & $\begin{array}{c}\delta^{\mathbf{3 4}} \mathbf{S}_{\text {sulfate-sulfide }} \\
6\end{array}$ \\
\hline Nova Redenção & $+37,5(n=4)$ & $+14,5(\mathrm{n}=18)$ & 23 \\
\hline $\begin{array}{l}\text { Morro Agudo/ } \\
\text { Vazante }\end{array}$ & $+24,6(\mathrm{n}=19)$ & $\begin{array}{l}\text { Orebody } N \\
-3,7(\mathrm{n}=13) \\
\text { Orebody } M \\
+34(\mathrm{n}=3) \\
\text { Orebody JKL } \\
\quad+21,7(\mathrm{n}=19) \\
\text { Orebody } G H I \\
\quad+29(\mathrm{n}=6) \\
\text { Vazante } \\
\quad+15,2(\mathrm{n}=5)\end{array}$ & $\begin{array}{c}28,3 \\
- \\
2,9 \\
- \\
9,4\end{array}$ \\
\hline Caboclo & - & $-3,2(\mathrm{n}=8)$ & - \\
\hline
\end{tabular}

The strong influence of underlying basement rocks in the supply of metals to the deposits is suggested by $\mathrm{Pb}$ isotope data (Table 1) and this aspect is discussed by Iyer et al. (2000). Approximate ages of the source rocks calculated from the $\mathrm{Pb}-\mathrm{Pb}$ secondary isochrons obtained from galena of the Caboclo deposit and from sulfides of the Irecê mineralization (Figure 5) are respectively 2.2 and $1.7 \mathrm{Ga}$. These ages correspond to two important events (see Figure 3 ) that formed U-Th$\mathrm{K}$ rich granites: a) The peraluminous leucogranites at $2-2.2 \mathrm{Ga}$ in the Jacobina-Contendas Lineament, with $\mathrm{U}=4-40 \mathrm{ppm}$ and $\mathrm{Th}=6-32$ ppm (Sabaté et al., 1990) and the alkaline to sub-alkaline magmatism, at $\sim 1.7 \mathrm{Ga}$, with $\mathrm{U}=4-20 \mathrm{ppm}$ and $\mathrm{Th}=15-76 \mathrm{ppm}$ (Maruéjol et al., 1987). On a Bouguer gravity map of the São Francisco Craton (Ussami, 1993), the deposits of Irecê, Nova Redenção, Serra do Ramalho, Itacarambi and some other $\mathrm{Pb}-\mathrm{Zn}$ occurrences of the $\mathrm{São}$ Francisco Basin appear to be associated with circular to oval-shaped negative anomalies with amplitude below - 65 mGal (Figure 3), suggesting that these deposits are genetically linked with the underlying rock bodies causing the anomalies. This kind of anomalies are normally associated with uranium-rich granites (Sangster et al, 1998) and thermal perturbation (Fehn et al., 1978). The high temperature values obtained from fluid inclusions of sphalerites in the deposits of Nova Redenção and Irecê (up to $250^{\circ}$ ) and an unusually high paleo-geothermal gradient calculated for the upper and middle crust of the São Francisco Craton (Iyer et al., in prep.) suggest the participation of a high temperature source in the formation of the deposits. The high geothermal gradient could have generated a convective system inducing the circulation of the mineralizing hydrothermal fluids for the Meso and Neoproterozoic mineralizations. In addition to the high permeability of the basement rocks and the low thermal conductivity of the sediments, the presence of pelitic cap rocks of low permeability helped reducing cooling of the system by rapid ingress of meteoric water, a condition considered essential by Sangster et al., 1998. This condition is satisfied by the deposits studied, which are capped by pelitic sediments. Figure 6 illustrates the proposed model discussed above.

Ackowledgements This study is part of our contribution to the IGCP Project 450 "Proterozoic sediment-hosted base metal deposits of Western Gondwana". We are grateful to John Ross for his valuable comments. This research is suported by FINEP/PADCT and CNPq grants to A.M. It is also partially suported by CBPM, CMM, SGM and CPRM. 


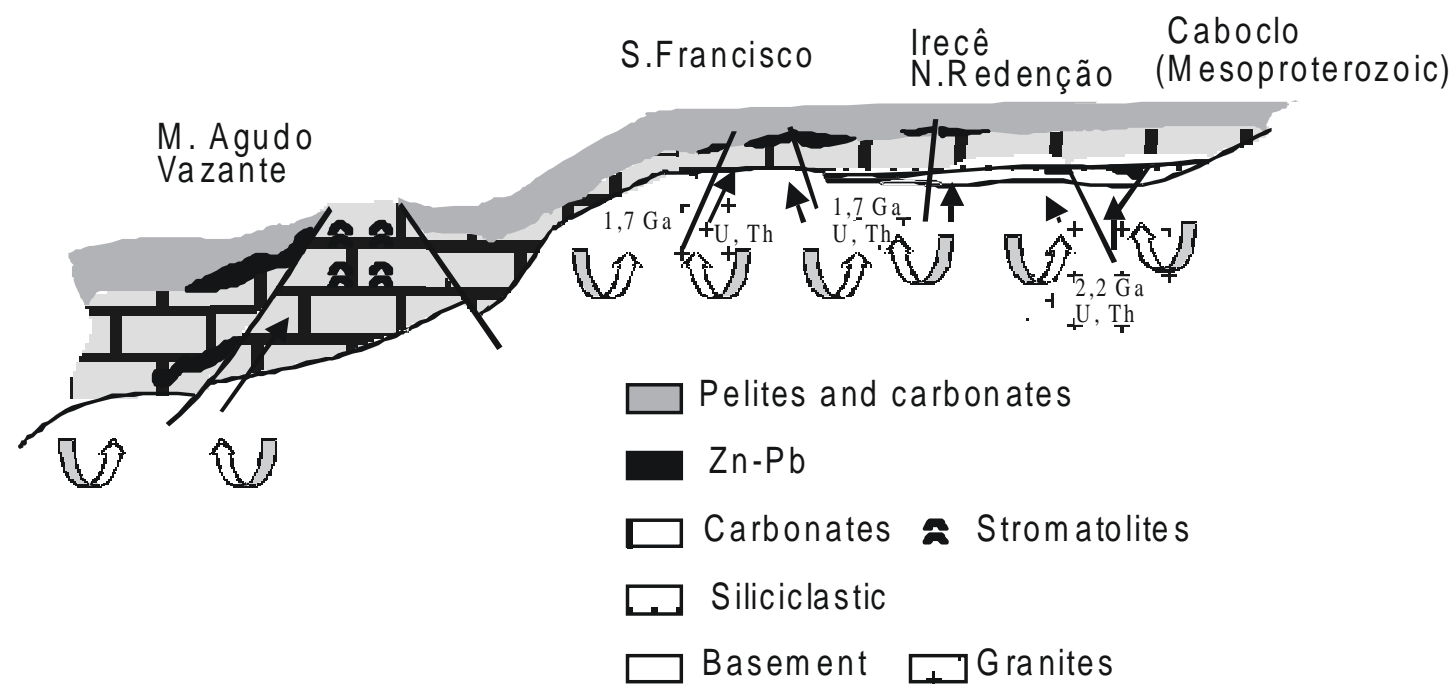

Figure 6-A possible evolution model (simplified) for the Proterozoic sediment-hosted Zn-Pb deposits of the São Francisco Craton.

\section{References}

Amaral G. 1968 Aplicação do estudo da composição isotópica do chumbo a problemas metalogenéticos: Resultados preliminares para galenas de depósitos do Grupo Bambuí. XXII Congresso Brasileiro de Geologia, Sociedade Brasileira de Geologia Anais, p. 131-138.

Cassedanne J. \& Lassère M. 1969. Étude géologique et anlyses isotopiques par la méthode au plomb de quelques galenas du Brésil. Bureau de Récherches Géologiques et Minières, Bull., série 2 section 4 p. 71-87.

Claypool G.H., Holser W.T., Kaplan I.R., Sakai H., Zak I. 1980. The age curves of sulfur and oxygen isotopes in marine sulfate and their mutual interpretation. Chem. Geol., 28: $199-260$.

Dardenne M.A. \& Freitas-Silva F.H. 1999. Pb-Zn ore deposits of Bambui and Vazante Groups in São Francisco Craton and Brasilia Fode Belt, Brazil. In: M.G. Silva \& A Misi (eds.), Base Metal Deposits of Brazil, MME/CPRM/DNPM, Belo Horizonte, p. $75-83$.

Fehn U., Cathels L.M., Holland H.D. 1978. Hydrothermal convection and uranium deposits in abnormally radioactive plutons. Econ. Geology, 73:1556-1566.

Iyer S.S., Hoefs J., Krouse H.R. 1992. Sulfur and lead isotope geochemistry of galenas from the Bambuí Group, Minas Gerais, Brazil-implications for ore genesis. Econ. Geology, 87:437-443.

Iyer S. S., Marinho M. M., Babinski M., Misi A., Silva M.G., Toulkeridis T., Barbosa J. S F. 2000. Lead isotope evolution curve for the São Francisco Craton, Brazil, XXX International Geological Congress, Aug. 7 - 17, Rio de Janeiro.

Kyle J.R. and Misi A. 1997. Origin of Zn-Pb-Ag sulfide mineralization within Upper Proterozoic phosphate-rich carbonate strata, Irecê Basin, Bahia, Brazil. Intern Geology Review, 39:383-399.

Maruéjol P., Cuney M., Fuzikawa K., Netto A.M., Poty B. 1987. The Lagoa Real subalkaline granitic complex, south Bahia, Brazil: a source for uranium mineralization associated with Na-Ca metasomatism. Rev. Bras. Geociências, 17:578-594.

Misi A. 1999. Um Modelo de Evolução Metalogenética para os Depósitos de Zinco e Chumbo Hospedados em Sedimentos Proterozóicos de Cobertura do Cráton do São
Francisco (Bahia e Minas Gerais).Tese para concurso de Professor Titular, Universidade Federal da Bahia, Salvador, 151 p..

Misi A., Iyer S.S.S., Tassinari C.G.G., Coelho C.E.S., Kyle J.R., Franca-Rocha W.J.S. Gomes A.S.R., Cunha I.A., Carvalho I.G., Conceição Filho V.M. 1999 - Integrated studies and metallogenic evolution of the Proterozoic sediment-hosted $\mathrm{Pb}-\mathrm{Zn}-\mathrm{Ag}$ sulfide deposits of the São Francisco Craton, Brazil. In: M.G. Silva \& A. Misi (eds.), Base Metal Deposits of Brazil, MME/CPRM/DNPM, Belo Horizonte, p. 84-91.

Monteiro L.V.S. 1998. Contribuição à Gênese das Mineralizações de Zinco da Mina de Vazante, Minas Gerais. Dissert. Mestrado, Universidade de São Paulo, 159 p.

Romagna G., Costa R.R. 1988. Jazida de zinco e chumbo de Morro Agudo, Paracatú, Minas Gerais. In: C. Schobbenhaus and C.E. Coelho (Eds), Principais Depósitos Minerais do Brasil, DNPM/CVRD, v. 3 pp. 111-121.

Sabaté P., Marinho M.M., Vidal P., Caen-Vachette M. 1990. The 2 Ga peraluminous magmatism of the Jacobina-Contendas Mirante belts (Bahia, Brazil): Geological and isotopic constraints on the sources. Chemical Geology, 83:325-338.

Sangster D.F. Savard M.M. Kontak D.J. 1998. A genetic model for mineralization of Lower Windsor (Viséan) carbonate rocks of Nova Scotia Canada. Econ. Geology, 93:932-952.

Ussami N. 1993. Estudos geofísicos no Cráton do São Francisco: estágio atual e perspectivas. In: J. M. L. Dominguez \& A. Misi (eds), O Cráton do São Francisco, SBG BA-SE/SGM/CNPq, Salvador, BA, p. 35-43.

Zartman R.E. \& Doe B.R., 1981. Plumbotectonics - the model. Tectonophysics, 75:135-62.

Contribution IGC-196

Contribution IGC-196
Received March 3, 2000 Accepted for publication May 10, 2000 